\title{
i
}

\section{Tradução, paródia, estilização: A propósito da tradução de Os Malavoglia para o português Homero Freitas de Andrade}

RESUMO: Sáo tratadas questóes de tradução literária, por meio do exame da metodologia utilizada e das soluçóes encontradas durante o processo de traduçáo para o português do romance Os Malavoglia, de $\mathrm{G}$. Verga.

PALAVRAS-CHAVE: tradução literária; Os Malavoglia; prosa italiana do séc. XIX.

Sempre que me pediram aqui na faculdade para criar alguma disciplina sobre tradução, eu me fiz de desentendido. Sempre que me pediram para falar sobre traduçáo em algum evento científico, eu saí pela tangente. Nunca me empenhei muito em assistir a esse tipo de evento, e li, mais por dever de oficio, as principais obras teóricas sobre o tema. Porém, a tradução, ou melhor, a prática da tradução sempre fez parte das minhas atribuiçōes acadêmicas, seja no tempo de estudante, seja como professor de literatura estrangeira. E também, como tradutor, a prática da tradução, por menos que deseje teorizar sobre ela, sempre esteve no centro das minhas preocupaçōes.

Minha dificuldade de falar sobre o tema advém tanto da possibilidade de conseguir apenas repetir o que já foi dito pela literatura especializada, como também da eventualidade de não trazer nenhuma contribuição interessante para a discussão do problema.

Da leitura das várias teorias especializadas ficou-me a impressão de que, quando se trata de traduçáo literária, essas obras evitam ir muito além de estabelecer certas premissas, limitando-se a propor técnicas que servem de base para qualquer boa 
tradução. Ou então, quando fazem tabula rasa das tais premissas, o simples domínio das técnicas basta para esses teóricos, e, a seguir esta receita, o que geralmente se obtém como resultado é um texto final de linguagem pasteurizada, típica da tradução de best-sellers ou das legendas de filmes.

A primeira premissa, a de que todo tradutor é um traidor, é indiscutivel e deve ser dada por descontada pelo tradutor de literatura; do contrário, ele não teria como encarar o ofício.

Da leitura de ensaios de Pound e de Haroldo de Campos, ambos poetas e tradutores, me ficou o ensinamento de que, no caso da tradução de obras literárias, e tendo em vista justamente a necessidade de preservação do seu caráter artístico, a traição só poderia ser perpetrada por um escritor ou poeta.

A prática da traduçáo literária por anos a fio me levou a concordar humildemente com essa segunda premissa. A traduçáo de um texto literário, pelo que tenho podido observar, requer muitas vezes que o tradutor utilize no processo tradutório procedimentos semelhantes àqueles que usou o escritor para compor a obra. E desta perspectiva que eu pretendo falar de certas questóes que me foram suscitadas durante a tradução que Aurora Bernardini e eu fizemos de Os Malavoglia (São Paulo, Ateliê Editorial, 2002).

Publicado em 1881, o romance, segundo o prefácio de sabor marcadamente verista do próprio Verga, pretende ser "o estudo sincero e desapaixonado de como, provavelmente, devem nascer e desenvolver-se nas condiçōes mais humildes as primeiras inquietaçóes pelo bem estar; e que perturbação deve trazer a uma pequena família, que viveu até então relativamente feliz, a vaga cobiça do desconhecido, o perceber que não se está bem, ou que se poderia estar melhor"

"Quem observa tal espetáculo, - conclui o autor, expondo seu próprio método de criação, - não tem o direito de julgá-lo"; cabe-lhe apenas "restituir a cena nitidamente, com as cores devidas, de modo a dar a representaçáo da realidade como ela foi, ou como deveria ter sido."

A representação da realidade em Os Malavoglia se faz através desse observadornarrador, cuja voz, num jogo muito bem articulado de discursos direto, indireto 
e indireto livre, é ao mesmo tempo portadora e somatória de todas as vozes da narrativa, com suas particularidades de dicção regional, de repertório lingüístico, de gestos sonoros etc. A realidade é representada ao leitor a partir da língua, dos usos e costumes vigentes numa pequena aldeia de pescadores da Catânia, Sicília, onde a história acontece. Ali é recriada uma realidade que passa por transformaçōes sócio-econômicas e culturais profundas, capazes de mudar para sempre a fisionomia do lugar. Esse mundo em desagregação não pode mais ser entendido com base na sabedoria popular acumulada pela comunidade e expressa nos provérbios, nos modos de dizer, nos lugares-comuns e nas frases feitas que passaram de geraçäo a geração.

Para tentar recuperar artisticamente em português não só o tom da narrativa, mas também os efeitos causados pela manipulação dos vários procedimentos literários que a compóem, foi necessário, muitas vezes, recorrer à paródia e à estilização como instrumentos no processo de tradução.

Refiro-me aqui a uma das acepçōes que Iúri Tyniánov dá ao termo paródia'. A primeira, e mais conhecida, seria a de contracanto, ou canto paralelo, ou seja, a paródia que imita por oposição. Mas há um significado da palavra ao qual os teóricos do assunto quase nunca dão a devida importância e que está ligado a outra possibilidade de tradução do prefixo grego "para" como "ao lado de" Isso nos permite pensar num procedimento paródico por identidade, que Tyniánov chama de estilização. E explica:

A estilização está próxima da paródia. Uma e outra levam uma vida dupla: por trás do plano da obra existe um outro plano, o plano que é estilizado ou parodiado. Mas na paródia é necessária a desarticulação dos dois planos, o deslocamento de ambos; paródia da tragédia será a comédia [...], paródia da comédia pode ser a tragédia. Na estilização, ao contrário, existe a correspondência exata entre ambos os planos; entre o plano estilizante e o estilizado que se deixa entrever no primeiro.

1. Cf. "Dostoevskij e Gogol': per una teoria della parodia", in Avanguardia e tradizione, trad. Sergio Leone, Bari, Dedalo Libri, 1968. 
Um exemplo da utilizaçáo desse procedimento no processo de traduzir seria a recriação em português de um provérbio que não existe.ou não apresenta equivalência em nossa língua. A soluçáo encontrada foi parodiar a construçáo frásica típica dos provérbios, estilizando em português uma forma proverbial, que dá ao leitor a ilusão de ter sempre existido. Aliás, o próprio Verga também faz isso algumas vezes. Vejam-se alguns resultados:

a. perché il motto degli antichi mai mentì - porque dos antigos o mote náo mente jamais;

b. senza pilota barca non cammina - sem piloto a nau não dá quinau;

c. chi ha carico di casa non può dormire quando vnole - quem tem casa pra sustentar não tem querer deitar;

d. chi comanda ha da dar conto - quem tem mando náo abandona o comando;

e. 'ntroi 'ntroi, ciascuno coi pari suoi - lé com lé, cré com cré; cada qual com seu igual;

f. La ragazza comê educata e la stoppa comê filata - a moça como é criada a estopa como é fiada;

g. a donna alla finestra non far festa - mulher que vive à janela náo merece trela;

h. scirocco chiaro e tramontana scura, mettiti in mare senza paura - siroco claro e norte escuro, lança-te ao mar seguro.

Procedimento semelhante foi utilizado ainda na tradução dos dois parágrafos iniciais do romance, bem como em outras ocasiôes, geralmente quando ocorriam digressōes por parte do narrador. $O$ objetivo era recuperar em português certas peculiaridades estilísticas que, no original, decorrem do recurso à paródia, à estilizaçáo e à intertextualidade. Nos primeiros parágrafos, por exemplo, para descrever Aci Trezza e seus habitantes, bem como para conferir grandeza e dignidade épica à minúscula e desimportante aldeia da Catânia, Verga parodia e/ou estiliza modelos de exórdios clássicos da literatura italiana. A soluçáo em português foi estilizar o discurso de modo a conceder-lhe uma cadência típica de rememoraçăo e, com inversōes e deslocamentos sintáticos, além da escolha de expressóes e palavras de 
um repertório característico da literatura do século XIX, conferir-lhe uma pátina classicizante. Assim, o leitor tem a impressáo de que a forma ou o modelo parodiado na traduçāo encontram eco em sua própria tradição literária. Como exemplo, veja-se o resultado obtido no primeiro parágrafo:

"Em outros tempos os Malavoglia tinham sido numerosos como as pedras da estrada velha de Trezza; e deles havia até em Ognina, e em Aci Castello, todos boa e brava gente do mar, bem ao contrário do que parecia pela alcunha, como sói acontecer. Realmente, no livro da paróquia chamavam-se Toscano, mas isso não queria dizer nada, pois desde que o mundo é mundo, em Ognina, em Trezza e em Aci Castello, sempre tinham sido conhecidos como os Malavoglia, de pai para filho, que sempre tiveram barcos na água e telhas ao sol. Agora em Trezza só restavam os Malavoglia do patráo 'Ntoni, aqueles da casa da nespereira, e da Providência que ficava na encosta do areal, debaixo do lavadouro, perto da Concetta do tio Cola, e da chalupa do patrāo Fortunato Cipolla"

De qualquer modo, importa ao tradutor de textos literários recriar na sua língua o modo específico do uso da linguagem, que caracteriza não só o autor traduzido, mas sua época, sua escola e o gênero de sua produçáo. Com base num sistema de compensaçăo, que implica tentar recuperar sempre as perdas ocorridas no processo tradutório, o tradutor deve reinventar em sua língua o estilo do escritor traduzido com base na diç̧ão, na sintaxe, na imagética, no ritmo e no uso de figuras e de outros meios lingüísticos que conformam o texto original. Só assim, sua tradução será o resultado de uma operação dialógica entre as duas literaturas, entre as culturas em questáo.

ABSTRACT: Si discutono questioni di traduzione letteraria mediante l'analisi della metodologia utilizzata e delle soluzioni trovate durante la traduzione in portoghese del romanzo I Malavoglia, di Giovanni Verga.

PAROLE CHLAVE: traduzione letteraria; I Malavoglia; prosa italiana dell'Ottocento. 